\title{
A Study on Snail Species Present in Mgbowo Awgu Local Government Area, Nigeria
}

\author{
Nwadike Chidiogo Comfort ${ }^{1, *}$, Ude Chidelum Jennifer ${ }^{2}$, P. C. O Ilozumba ${ }^{2}$ \\ ${ }^{1}$ Department of Integrated Science, Nwafor Orizu College of Education, Nigeria \\ ${ }^{2}$ Department of Zoology, Nnamdi Azikiwe University, Nigeria
}

Received December 24, 2019; Revised April 2, 2020; Accepted April 12, 2020

Copyright $\bigcirc 2020$ by authors, all rights reserved. Authors agree that this article remains permanently open access under the terms of the Creative Commons Attribution License 4.0 International License

\begin{abstract}
A study of snail species in Mgbowo Community Awgu L.G.A., Enugu State, Nigeria was undertaken from August to September, 2016. Five plots with different ecological features were mapped out for the study and the sampling methods used were handpicking and deep netting. A total of 397 snails belonging to two families and six species were collected. The snail species identified were Achatina achatina, Achatina margnata, Achatina fulica, Lanistes various Limicolaria martensis and Limicolaria aurora. The most abundant species was $A$. achtina with 127 individuals and a relative abundance of $31.98 \%$. It was followed by $A$. margnata, L aurora, A. fulica and L martensis with relative abundance of $24.2 \%, 19.4 \%, 12.34 \%$ and $8.8 \%$. Lanistes varicus was the least abundant with 13 individuals and a relative abundance of $3.30 \%$. The plots differed in diversity and abundance, plot A; 114, plot B: 67, plot C. 82, plot D: 49 and plot E. 85. Lanistes varicus which was collected in the present study are listed in the International Union for conservation of Nature (IUCN) Red list as an endangered species as well as promoted intermediate host for Schistosoma species, so there is a need to adopt a sustainable approach in the utilization and conservation of snail species in Mgbowo community. Limicolaria species is a vector of rat lungworm Angrostronglus cantonesis. The study has helped to identify the diversity of snails living within Mgbowo community and their habitats. Thus, this study revealed that Mgbowo Community has low snail diversity. Again, snail picking by farmers and indigenes of Mgbowo for meat is negligible but may prove to be detrimental to the population of snails in the community in the near future.
\end{abstract}

Keywords Snail, Species, Family, Diversity, Abundance, Conservation, Distribution

\section{Introduction}

Snails belong to the class of Gastropoda, a classification that includes land, freshwater and sea snails as well as slugs. Gastropods belong to the phylum Mollusca a classification of invertebrate animals with soft unsegmented body, sometimes covered with an exoskeleton or shell. Snails and slugs are both Gastropods, therefore they are closely related, and regardless the fact that slugs lack a protective shell [1]. Adegoke et al [2] reported that snail meat is high quality food rich in protein, a good source of iron and low in fats. Land snails collected from the forest have traditionally been a major part of the West African diet [3]

Snail farming in Nigeria ranges from backyard small farms to small scale snailery, to large scale commercial scale farm [4]. Snails could also be gathered from the wild and could sometimes have high mortality rate as they try to adapt to new conditions [5]. Land snails form an important component in the forest eco system [6] and they also have the largest number of documented extinctions of any major taxonomy group [7]. The major threat to the native land snail fauna include habitat loss and fragmentation as a result of anthropogenic activities such as intense land use, construction of roads, dams, plantations, pollution and spread of invasive species [8] which reduce diversity and change community structure of land snails [9].

Snails are found in Mgbowo community in Awgu Local Governement Area of Enugu state. Studies on ecology of snails showing the abundance, diversity and habitat preference have been carried out in some part of Nigeria [10] [11] [12] [13] [14]. However, no such studies concerning snail fauna of Mgbowo community in Awgu Local Government Area of Enugu State, Nigeria.

The aim of this study is to provide information on the snail species of Mgbowo community in Awgu L.G.A of Enugu State Nigeria by identifying the snail species found in Mgbowo community, by ascertaining the 
distribution of the snail species in different biomes of Mgbowo community and then to ascertain the diversity and abundance of the snail species in different habitats in Mgbowo community.

\section{Methodology}

The study was carried out at Mgbowo Community which is located in Awgu Local Government Area of Enugu State,
Nigeria. It falls within the geographical co-ordinates of longitude $06^{0} 31^{\circ} \mathrm{N}$ and $07^{\circ} 27^{\circ} \mathrm{N}$ and latitudes $07^{\circ} 35^{\prime} \mathrm{E}$. Mgbowo is situated in the tropical rainforest zone which experiences five months of dryness (November-March) and seven months of rainfall (April-October). The maximum temperature is about $34.8^{\circ}$ while minimum temperature is $19.8^{\circ} \mathrm{C}$. Maximum relative humidity is $99 \%$ in October and November while the minimum relative humidity is $37 \%$ in February, September being the most humid month and February being the least humid month [15] [16].

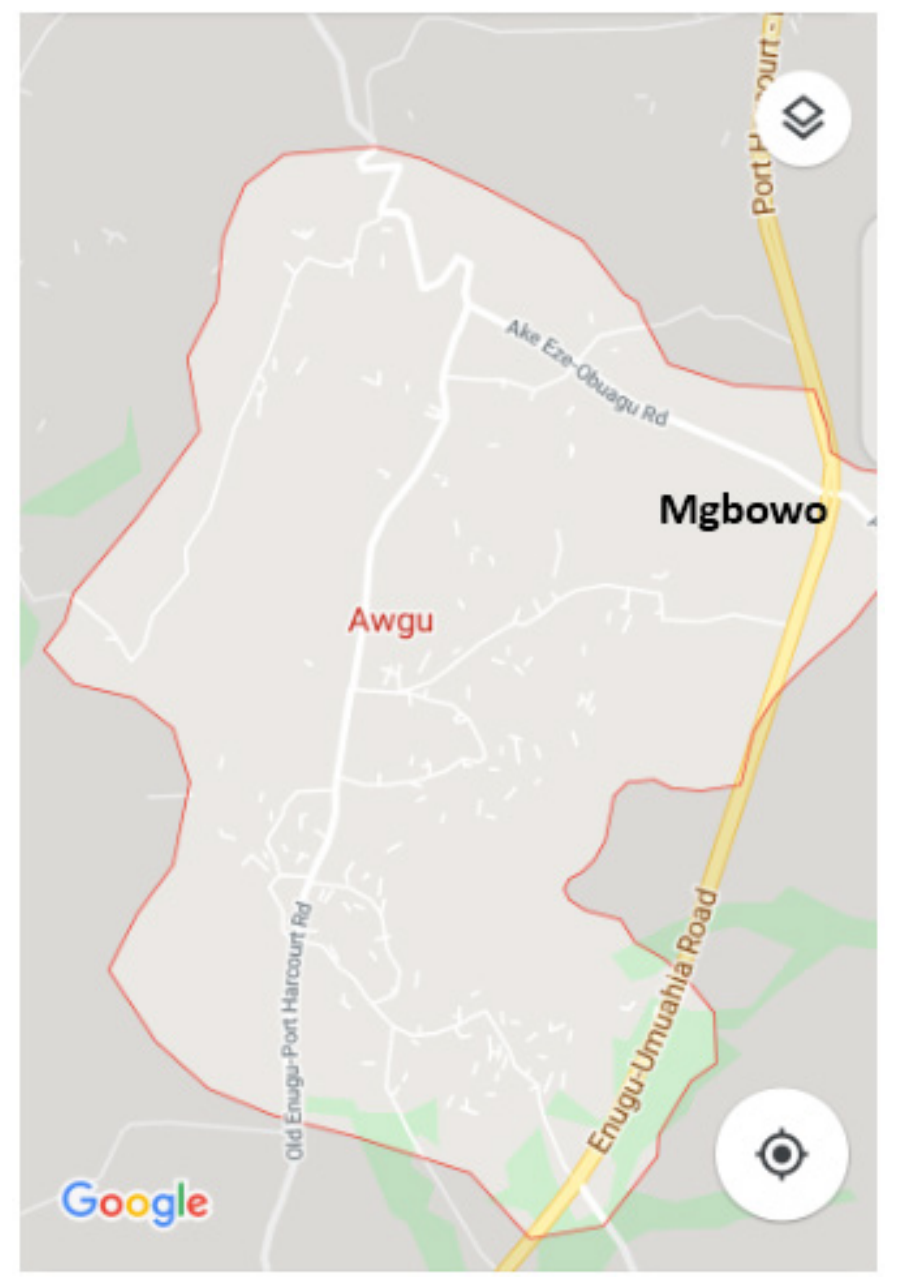


A preliminary survey was undertaken with a view of identifying areas where snails could be found. These areas were apportioned and assigned plot A, B, C...E. Deep net method and handpicking techniques were used for the sampling. The deep net used during the sampling period was made from a mesh of mosquito nets with a circular mouth of diameter $25 \mathrm{~cm}$ rimed with a metal handle. Snails were caught by sweeping the net through the water thereby collecting snails clinging to aquatic plants. Snails were also handpicked from farmlands, banana and plantain leaves, tree branches, stream and river side vegetation while wearing hand gloves. The snails were marked with numbers and immediately put in a basin containing stream water and vegetation and taken to the Zoology Department Laboratory of Nnamdi Azikiwe University for sorting and identification. The collected snails were identified to species level using relevant literatures with the assistance of Dr. T. Mogbo of the Department of Zoology, Nnamdi Azikiwe University, Awka. The species abundance and diversity were statistically analysis using Simpson's Diversity Index.

\section{Results}

Table 1. Showing the number of snails collected from different plots

\begin{tabular}{|c|c|}
\hline Plots & Total number of snails \\
\hline Plot A & 114 \\
\hline Plot B & 67 \\
\hline Plot C & 82 \\
\hline Plot D & 49 \\
\hline Plot E & 85 \\
\hline Total & $\mathbf{3 9 7}$ \\
\hline
\end{tabular}

Table 1 shows that a total of 397 snails we collected from the 5 plots. In plot A one hundred and fourteen (114) snails were collected, sixty seven (67) snails from plot B, eighty (80) snails from plot $\mathrm{C}$, forty nine (49) snails from plot D and eighty three (83) snails from plot E as depicted by the result.

Table 2. Showing species of snails collected from the Mgbowo community study area

\begin{tabular}{|c|c|c|c|}
\hline S/N & Snail Species & $\begin{array}{c}\text { Number of } \\
\text { individual species }\end{array}$ & Snail families \\
\hline 1 & $\begin{array}{c}\text { Achatina } \\
\text { achatina }\end{array}$ & 127 & Achatinidae \\
\hline 2 & $\begin{array}{c}\text { Achatina } \\
\text { marginata }\end{array}$ & 96 & Achatinidae \\
\hline 3 & Achatina fulica & 49 & Achatinidae \\
\hline 4 & Lanistes varicus & 13 & Ampullariidae \\
\hline 5 & $\begin{array}{c}\text { Liicolaria } \\
\text { martensis }\end{array}$ & 35 & Achatinidae \\
\hline 6 & $\begin{array}{c}\text { Limicolaria } \\
\text { arora }\end{array}$ & 39 & Achatinidae \\
\hline
\end{tabular}

Table 2 shows that a total of six snail species belonging to two (2) families were found namely, Achatina achatina, Achatina marginata, Limicolaria aurora, Achatina fulica, Limicolaria martensis and Lanistes varicus with 127, 96, 77, 49, 35 and 13 individuals respectively. Achatina achatina is the most abundant while Lanistes varicus was the most least abundant as indicated by the result. The table also showed that the 6 species of snails collected in the study belong to 2 families, the Achatina and Limicolaria species belong to the family, Achatinidae while the Lanistes varicus belong to the family Ampullariidae.

Table 3 shows that a total of 397 snails were collected from all the five (5) plots visited. The result revealed that Achatina achatina (127) was the most abundant followed by Achatina marginata (96), Achatina. Aurora (77), Achatina. fulica (49), Limicolaria martensis (35) while Lanistes varicus (13) was the most least abundant as depicted by the result. The result also showed that Lanistes varicus was only present in plot A. This could be seen as an indication that it is the most endangered snail species in the Mgbowo community and thus, calls for conservation.

Table 3. Showing distribution of snail according to the plots sampled

\begin{tabular}{|c|c|c|c|c|c|c|}
\hline Snail Species & Plot A & Plot B & Plot C & Plot D & Plot E & Total \\
\hline A. achatina & 54 & 14 & 18 & 17 & 24 & 127 \\
\hline A. Marginata & 14 & 19 & 28 & 7 & 26 & 96 \\
\hline A. fulica & 4 & 14 & 12 & 4 & - & 13 \\
\hline L. varicus & 13 & - & - & - & 8 & 35 \\
\hline L.martensis & 5 & 7 & 9 & 6 & 12 & 77 \\
\hline L.Aurora & 24 & 13 & 15 & $\mathbf{4}$ & $\mathbf{8 5}$ & $\mathbf{3 9 7}$ \\
\hline Total & $\mathbf{1 1 4}$ & $\mathbf{6 7}$ & $\mathbf{8 2}$ & $\mathbf{4 9}$ & \\
\hline
\end{tabular}


Table 4. Showing diversity of snail using Simpson's Index Method

\begin{tabular}{|c|c|c|}
\hline Snail Species & $\mathbf{N}$ & $\mathbf{N}(\mathbf{n}-\mathbf{1}) \mathbf{D}=\sum(\mathbf{n} / \mathbf{N})^{\mathbf{2}}$ \\
\hline A. achatina & 127 & 160020.22 \\
\hline A. Marginata & 96 & 9120 \\
\hline A. fulica & 49 & 2352 \\
\hline L. varicus & 13 & 156 \\
\hline L.martensis & 35 & 1190 \\
\hline L.Aurora & 77 & 5852 \\
\hline & $\mathrm{N}$ & $\sum \mathrm{n}(\mathrm{n}-1)$ \\
\hline & 397 & 34672 \\
\hline
\end{tabular}

The table 4 shows that the Simpson's index value of species diversity was 0.22 . This is an indication that it had low diversity and so, calls for urgent conservation measure as depicted by the result. The anthropogenic and natural factors could account for the low species diversity.

Table 5. Showing the relative abundance of snail species

\begin{tabular}{|c|c|c|c|c|}
\hline Snail Specie & N & N & $\begin{array}{c}\text { D(relative } \\
\text { abundance) }\end{array}$ & $\begin{array}{c}\text { Relative } \\
\text { Abundance \% }\end{array}$ \\
\hline Achatina & 127 & 397 & 0.1023 & 31.99 \\
\hline A. marginata & 96 & 397 & 0.1000 & 24.20 \\
\hline A. fulica & 49 & 397 & 0.0200 & 12.34 \\
\hline L. varicus & 13 & 397 & 0.0010 & 3.30 \\
\hline L. martensis & 35 & 397 & 0.0100 & 8.82 \\
\hline L. aurora & 77 & 397 & 0.0400 & 19.40 \\
\hline
\end{tabular}

The table 5 shows that Achatina achatina was the most abundant snail species in Mgbowo community with a relative abundance value of 0.1023 and making up $31.99 \%$ of snail collected. It was followed by Achatina marginata, Limicolaria aurora, Achatina fulica and Limicolaria martensis with a relative abundance of $0.10(24.20 \%), 0.04$ $(19.40 \%), 0.02(12.34 \%)$ and $0.01(8.82 \%)$ respectively. Lanistes varicus had the last relative abundance value of 0.0010 , making up only $3.3 \%$ of the total snails collected as revealed by the result.

\section{Discussion}

In the study, a total of 397 snails were collected from the study area with Achatina achatina being the most abundant species, making up $31 \%$ of the total number of snail species collected with 127 individuals. Followed by Achatina marginata, Limicolaria aurora, Achatina fulica and Limicolaria martensis with 96 (2.4\%), 77 (19\%), 49 (12\%) and $35(8 \%)$ respectively. Lanistes varicus had the lowest number of snails collected with 13 snails. The number of snails sampled in some plots of study differed when compared with other study areas. A. achatina was found in all 5 plots but most abundant in plot A. Limicolaria martensis and Limicolaria aurora were not abundant in the present study. This is in line with Oke and Aloban [17] who in their study on land snail diversity in Okomu National Park, Edo State recorded Pseudopea species as the most abundant species and identified Limicolaria as a rare species. The abundance of $A$. achatina and others in the study could be as a result of the availability of food materials and favorable environmental condition. An observation made by Rusieck [18] stated that snails preferred habitats rich in vegetation and moisture because such environments contain soil salts and nutrient such as calcium carbonate, which help in the formation of solid shells. A similar observation was made by Ebenso [19], where he identified Limicolaris species as one of the least abundant species in Nigeria, because of the species poor adaptive nature.

Again, according to the findings of the present study, Lanistes varicus was the only fresh water snail collected in the study area. The species was also the least abundant with 13 individuals collected. However, in a survey on aquatic snail species of two adjoining River (Otarniri and Nwaorie Rivers) in Owerri South Eastern Nigeria, Oguoma et al [20] had no record of Lanistes various. Instead, the study identified 231 aquatic snails of 3 species.

The table 4 shows that the Simpson's index value of species diversity was 0.22 . This is an indication that it had low diversity and so, calls for urgent conservation measure as depicted by the result. The low diversity observed in the study could be as a result of human disturbances such as construction of residential buildings. Urbanization is a major cause of change in species diversity and richness [21][22]. According to Lush [23], noise from vehicles affects most snail species in a negative way, causing them to flee from such areas. Lush [23] observation is in line with Mgbowo community because snails were not found near roads except at night when vehicle traffic was at minimum.

\section{Conclusions}

Recent studies clearly indicate that interest in snails has increased tremendously over the past decades, with researchers from many disciplines in both developed and developing counties focusing on this unique and diverse creatures. Mgbowo community and the general public need to be enlightened on the benefits of snails to the environment and ecosystem and their economic importance. The study has helped to identify the diversity of snails living within Mgbowo community and their habitats. Thus, this study revealed that Mgbowo Community has low snail diversity. Again, snail picking by farmers and indigenes of Mgbowo for meat is negligible but may prove to be detrimental to the population of snails in the community in the near future. Lanistes varicus one of the snail specie collected in study has been listed and identified by the International Union for Conservation of Nature (IUCN) as an endangered species. This situation 
suggests an important need not only for serious effort at conserving Mgbowo snail fauna but also for concerted effort at documenting the snail fauna of other communities in the Enugu State to enhance conservation and obviate extinctions of this valuable natural resource.

\section{REFERENCES}

[1] Inter-African Bureau for Animal Resources. A-Z Animals and Animal Facts, http://a-Z-animals.com/animals/snail/. 2019.

[2] Adegoke AA, Bukola AC, Compior IU, Olayinka AA, Amos KO. Snails meat source: Epidemiological and nutritional perspectives Journal of microbiology and Antimicrobial; 2 (1): 001-005, 2010.

[3] Ejidike BN. Snail rearing practices in Southern Nigeria. Proc. 27th Annual conference Nigeria society for animal production (NSAP). March 17-21, 2002, Akure, Nigeria. 2002 .

[4] Goodman AK. Giant African land snails. Retrieved 7th 2016 at 18:05pm. Ibom, L.A. (2009). Variations in Reproductive and growth performance traits of white skinned and Black skinned African Giant Snail hatchlings (Achatina marginata) in Obubra Nigeria. Ph.D. Thesis, Department of Animal science, University of Calabar, Nigeria. 2005.

[5] Ebenebe CI. Mini livestock Production in Nigeria. The present and the future. Prov 51 Annual conference, Animal science Association of Nigeria. (ASAN). Sept 19-22, 2000. Port Harcourt, Nigeria. 2000.

[6] Sandeep S, Ravi Kanth G, Aravind NA. Land snails (Mollusca, Gastropoda) of India a: status, threats and conservation strategies. JOTT Review; 4(11): 3029-3037, 2012.

[7] Lydeard CR, Cowie W, Ponde A, Bouchet S, Clark K, Cummings T, Frest OJ, Gargoming D, Herbert R, Perez B, Roth M, Seddon E, Strong A, Thompson L. The Global Decline in non Marine Mollucs. Bioscienece. 54:321-330, 2004.

[8] Aravind NA. Ecology of land snails of Western Ghats. PHD thesis, Department of Applied zoology, managalore University, Mangalore. 2003.

[9] Rajashekhar KP, Aravind NA. Perturbation in the pattern of Land snail diversity due to anthropogenic disturbance to wet green forests of the western Ghats, India. Invertebrate diversity and conservation in the western Ghats. A tree, Bangalore. Journal of Threatened Taxa; 4(11): 3029-3037, 2012.
[10] Solomon L. Special feasibility study report on snail farming in Bori, Rivers States, Nigeria. American Journal of Research Communication; 4(1): 138-164, 2013.

[11] Bukola CA, Abidun AO, Florence IE. Studies on Microbiological, Proximate Mineral and Heavy metal composition of freshwater snails from Nigeria Delta Greek in Nigeria. AUJ.T; 14(4): 290-298, 2011.

[12] Agbogidi MO, Okonta BC. Reducing poverty through snail fanning in Nigeria. Agriculture and Biology Journal of North America; 2(1): 169-172, 2011

[13] Ogogo AU, Ijeomah HM, Effiong KM. A survey of snail farming in Akwa Ibom State, Nigeria electronic Journal of Environmental. Agriculture and food Chemistry; 10:1935-1942, 2011.

[14] Ahmadu J, Ojogho O. Economics of snail production EdoState, Nigeria. International Journal of Agriculture Science; 4:233-237, 2012

[15] Anonymous. Federal Aviation Administration. Contact Approach. Aeronautical Information Manual. Washington, D.C. U.S. Department of Transportation. Namet, Lagos. 2010 .

[16] Anonymous. Latitude and Longitude of Major Town in Nigeria. Satellite T.V. Technology. 2012.

[17] Oke OC, Aloban FI. The land snail Diversity, in Asquaie Kilometa of Tropical Rainforest in Okomu National park, Edo State, Nigeria. Department of zoology, University of Benin, Benin City. Edo State, Nigeria. African Scientist; 7(3): 135-142, 2006.

[18] Ntonifor HN, Ajayi JA. Studies on the ecology and distribution of some medically important freshwater-snail species in Bauchi State, Nigeria. International Journal of Biological and Chemical Sciences; 2(1): 121-127, 2000.

[19] Ebenso IE, Etim L, Ndengo WU, Obasi OL. Slowly we are coming out: Salient Issues in Sustainable tropical Agriculture (SITE) faculty of Agriculture University of Oyo; 9:51-54, 2006.

[20] Oguoma IO. Aguatic Snail species of two Adjoining Rivers in Owerri, Imi State, South eastern Nigeria. Animal Research International; 7(1): 1125- 1128, 2010.

[21] John GF, Harcourt BA. Primate Adaptation and Evolution. Jehovah Publishers. New York. 1988.

[22] Izawa K. Foods and feeding Behaviour of Wild Black capped capuchi, (Cebus apeela). Primate; 19:42-633, 1979.

[23] Lush AL. Biology and Ecology of the introduced snail Micoxomagna atnillata in South Eastern Australia. Ph.D. Thesis, school of Agriculture, Food and Wine, University of Adelaide, Australia. 2007. 